\title{
Coordination of and through E-Government: The Case of the Czech Republic
}

David Špaček

\begin{abstract}
Although e-government as a research topic is rather embedded in public-administration literature, and coordination of and through e-government is visible in European countries, coordination of and through e-government has not been paid much attention. Consequently this paper deals with this topic. Its text outlines emerging coordination practices that can be observed in European countries, and it also indicates issues using the Czech e-government development and some key national initiatives as examples. The presented text concludes that although elements of strategic planning may become embedded and institutional and regulatory mechanisms stabilized in the country, other issues such as a weak accountability culture may exist and hinder coordination practices.
\end{abstract}

Keywords: e-government, coordination, accountability, Central and Eastern European public administration

\section{Introduction}

E-government is a fashionable research topic and has been a visible element of administrative reforms since the late 1990s. As Kudo (2008) points out, e-government represents a specific public policy; it is an overall policy, covering different economic sectors, and it deals with the policy-making process and the organization and management of government in general. As such, it inevitably raises discussions about its potential to improve government coordination through a more joined-up delivery of public services. E-government development also requires coordination

1 Assistant Professor, Department of Public Economics, Faculty of Economics and Administration, Masaryk University, Brno, Czech Republic. 
in order to bring improvements and enable the delivery of services through integrated one-stop shops, whether virtual or physical (Kunstelj and Vintar 2009).

Policy coordination across government is perceived as a key factor determining effective governance at the national level (Saner et al. 2008; de Vries and Nemec 2013). However, e-government coordination and coordination through e-government have not been paid much attention in research; we may find only a few studies focused on the governance of e-government (Löfgren 2007). This paper contributes to answering the following questions: What are the roles and trends of coordination of and through e-government, and what challenges may governments face when coordinating e-government and through e-government?

In order to answer these questions, the text outlines e-government complexity and current approaches to coordination of and through e-government in Europe. It also discusses whether e-government may enhance the coordination of publicservice delivery, employing selected examples from Czech e-government.

The paper draws attention to problems in policy, both in the institutional framework and in practical approaches to management. It is also concerned with the question of how new structures that have been established for e-government coordination hinder or support accountability.

The methodology on which the paper builds is based particularly on a literature review. International and Czech public-administration academic literature as well as official government documents were studied together with comments of affected stakeholders (including comments from interviews with representatives of main associations of self-governments and their top executives).

\section{E-government terminology}

The literature has used various labels to describe and discuss how information and communication technologies (ICTs) can and actually do achieve improvements in governance. Definitions of e-government still abound in the literature, and the available "e-gov" terminology indicates the complexity of the area. We do not see terms such as "digital government" or "online government" today as often as in the past, and terms such as e-government or e-governance are rather globalized. However, definitions may still vary in their specifics across approaches, and the field lacks a coherent identity (Hu et al. 2010).

In general, the terminology refers to the application of ICTs inside and surrounding public administration. ICTs are seen as enablers (sometimes even causes) of desired or desirable changes (Homburg and Snellen 2007) such as administrative simplification, speeding up of processes, enhancement of inclusion in public decision-making, etc. Successful e-government must involve more than just using ICTs and putting administrative services on the internet; it implies re-engineering, 
reorganizing and restructuring public organizations and shifting the focus towards a citizen- and customer-centred service provision (Makolm 2006; Chen 2010). Similarities are incorporated in various e-government maturity models (Siau and Long 2005) designed for benchmarking on the principle that users will be more satisfied with services provided in a fully electronic way, with the maximum integration of various back offices.

Sometimes a specific channel for service delivery is reflected in the current terminology. For example, m-government, using mobile phones, is being emphasized for the phone's broad penetration in society as a communication channel (Snellen and Thaens 2008). Specific instruments facilitating social networking are also discussed (labelled as e-government 2.0; see Accenture 2009). This implies that e-government coordination also concerns coordinating various communication channels. The available terminology emphasizes specific branches of new services (e-health, e-justice) and specific areas of processes that ICTs facilitates (e-invoicing, e-procurement and e-participation) (Špaček 2012a). Specialized terminology may help make e-government education and research more focused. It may omit the complexity of e-government, with linkages between individual channels and branches.

In this paper, the term "e-government" will be used in very general terms in order to cover initiatives that try to use ICTs to improve governance and will include information and transaction services for citizens and businesses as well as those from the field of e-administration that attempt to improve internal processes.

\section{E-government as an object as well as an instrument of coordination}

E-government ideas have been extensively translated into practice around the world in the last decade. In EU member states, we may now distinguish the following general trends of e-government (Špaček 2012a):

- establishing new and revising existing national portals that sometimes innovate their service-delivery mechanisms (e.g. by mobile IDs or enhanced personalization) or focus on a specific field of communication between government and businesses and/or citizens (including e-procurement, e-invoicing, e-health, ejustice, and e-environment);

- piloting e-participation/e-democracy projects (including e-voting, e-participation tools on national portals dedicated to legislation, experiments with econsultations for the identification of administrative burdens and communitybuilding projects);

- promoting more internationally-recognized instruments for electronic identification; 
- searching for instruments enhancing effectiveness and efficiency (e.g. more complex managerial information systems, new institutional arrangements for e-government coordination and evaluation).

These trends follow the recommendations and requirements of current EU information-society policies and the e-government action plan (European Commission 2010a and 2010b) that followed the former initiatives (eEurope, i2010), and they try to optimize conditions for cross-border e-government services. The trends must take place within the historical paths of individual countries and their achieved levels of e-government. They must also confront the fact that citizens still largely prefer physical contact with public administration (Tinholt and Linden, 2012).

Although e-government policies have always been ambitious and many projects have been implemented, gaps between the revolutionary potential of ICTs (egovernment hype) and the evolutionary reality (Heeks 2006) are still found. As the Organisation for Economic Co-operation and Development (OECD) has stated repeatedly, e-government is more about government than about "e" (OECD 2003 and 2009). This can be seen in the growing demand for better e-government management, including coordination and evaluation.

As a reaction, more centralization of e-government is currently visible in Europe, where central governments are clearly attempting to strengthen their coordination responsibilities. In doing so, governments work with combinations of the instruments enumerated by Estevez et al. (2007): providing guidance and control for implementing e-government projects across the government, providing frameworks for collaboration across agencies that ensure the interoperability and non-duplication of efforts and resources, developing shared e-government infrastructures, keeping e-government activities aligned with the broader government strategy and vision, and developing and implementing government policies related to the use of ICTs. Governments struggle with various levels of coordination (as presented by Metcalfe in Bouckaert et al. 2010), but central government policies explicitly emphasize the strategic role of cooperation among key e-government actors now much more than before.

The ePractice eGovernment factsheets indicate that new trends of coordination through e-government may include the following:

1. new central government services for public authorities have been launched, mainly since 2008. In Finland, for instance, a new portal of e-services (suomi.fi/workspace) was launched to provide access to selected e-services and e-forms (Epractice.eu 2012a). Web eFormulieren was launched in the Netherlands in order to offer free access to e-forms and provide a platform for their design and management (Epractice.eu 2011a). In Estonia, the centrally offered solution VOLIS attempts to support more participatory decision-making in local governments 
(Epractice.eu 2011b). The Hungarian government launched a call for a tender for the establishment of seven municipal Application Service Provider centres to increase the adoption and quality of e-government service (Epractice.eu 2014a). The project "eGovernment reference towns" was launched by the Austrian Federal Chancellor's office, the Association of Austrian towns (Städtebund) and the Austrian Digital Platform in order to gather experience, share good practices and promote the national e-government portal (Epractice.eu 2011c). New portals for sharing experiences may be built from the bottom - e.g., Swedish local authorities use the "Platform for Co-operative Use" (www.sambruk.se) to exchange best practices and speed the development of e-government in municipalities (Epractice.eu 2012b). The Dutch project GovUnited was launched to improve and standardize both the public services and the internal administration of local governments (Epractice.eu 2011a). In the case of centrally offered solutions, governments are using cloud computing, which may blur the lines of responsibility and make it harder to determine who is accountable for which results (as discussed with regards to public-private partnerships by Willems and Van Dooren 2011).

2. new duties, brought by legislation on access to public information, privacy protection and accessibility of electronic services as well as by e-government acts (such as Austrian Act no. 10/2004), which attempt to standardize electronic communication and its infrastructure, stipulate interoperability requirements (including those from European Interoperability frameworks) and link e-services to national portals; projects promoting/requiring the use of open-source solutions are also visible (see e.g. the Dutch Open Connection action plan for 2008-2012; see Epractice.eu 2011a);

3. the reorganization of existing or the establishment of new structures for national coordination of e-government and the (re)definition of their responsibilities. For example, in Italy, the new DigitPA body was established within the structures of the Ministry for Public Administration and Innovation in December 2009 in order to support the implementation of e-government strategies with technical support, consultation and evaluation (Epractice.eu 2011d). In July 2008, the new agency MITA was established in Malta to coordinate e-government strategy and development and ensure access of public authorities to the internet (Epractice. eu 2011e). In April 2010, a new IT planning council (IT-Planungsrat) was established as the body responsible for coordinating and steering inter-departmental e-government projects, replacing two former bodies. In order to support access to electronic public services, the Spanish strategy anticipated the establishment of a new ombudsman (Defensor del Usuario de la Administración Electrónica) (Epractice.eu 2012d). New duties may be prescribed to carry out ex ante and ex post evaluation of e-government projects, as anticipated, for instance, by the Danish 2007-2010 strategy where a new "Digital Taskforce" body was established as an inter-departmental committee for e-government. This body was ac- 
tive in providing public authorities with a methodology for elaborating business plans for e-government projects. In Denmark, a new fund, the PWT Foundation, was established in order to co-fund innovative projects (see Epractice.eu 2012c).

\section{Coordination and e-government - observations from the Czech Republic}

\section{Administrative fragmentation as a long-term challenge}

Czech e-government has been influenced by and reacting to changes brought by post-communist institutional reforms from the 1990s and early 2000s that were implemented in the name of democratization, decentralization and deconcentration. As a result there are currently two sub-national levels of government in the country: regional and municipal. Fourteen regions (established in 2000) and more than 6200 municipalities (of which the majority have less than 500 inhabitants) represent a fragmented system of territorial self-governments. Their bodies ("offices") may be required by law to exercise state-administration tasks (e.g. issuing identity cards, passports and various certificates and permissions). This so called "joined model" of territorial public administration has resulted in different categories of municipalities according to the amount of state administration they exercise, raising questions about the optimal funding of self-governments as well as about their political accountability for activities principally related to the central government. It has led to discussions about the capacities of self-governments to provide professional state-administration services in a uniform way as well as to questions about a minimum standard of e-government and a basic set of e-services that would be delivered by all (even small) municipalities.

Institutional reforms have also affected the capacity of the central government to coordinate and to use intermediary administrative levels (regions/districts) for coordination. In 2002, 77 district offices were abolished, although their state-administration functions (including overseeing municipalities and providing them with methodical help) had been established after a decade of existence. Subsequently, 205 municipalities were given the status of "municipalities with extended (state administration) responsibilities" ("ORPs"), but were not given the function of overseeing and methodically assisting smaller municipalities. This was transferred to 14 regions, a move which is still perceived negatively by some municipal representatives (Špaček and Špalek 2007).

The creation of 14 regions also raised questions about optimal territorial divisions and the ICT support of a highly fragmented state administration. State administration is exercised by self-governments and by the "deconcentrates" - specialized separate authorities - resulting from vertical deconcentration and existing within individual hierarchies of central authorities on various territorial levels. Their ad- 
ministrative territory followed (and in some cases still follows) the administrative territories specified under Communism in the 1960s (i.e. 77 districts and 8 "large" regions). The available numbers refer to almost 600 existing deconcentrates (including financial authorities, labour authorities, branches of various inspections and cadastral authorities). The first reform strategies (including the very first, from 1999: The Concept of Public Administration Reform) anticipated that the number of the deconcentrates would be substantially decreased by the creation of regions and the subsequent transfers of state administration tasks. The practical reform has actually not changed much, and various models are used which make the administrative system chaotic (some deconcentrates work on a territory of 14 regions, follow the regional divisions of self-governments and have branches in about 80 districts; the territories of others may also follow the 14 regions, but on a sub-level they follow the territories of ORPs, etc.).

The coordination problems were highlighted by general governmental documents on public-administration reform. The 1999 Concept of Public Administration Reform pointed out that "one of the major weaknesses of central government is a low level of horizontal coordination of individual subjects ... Totally dominating is the so-called functional management, which results in the illness of departmentalism." The departmentalization problem and the low level of horizontal coordination among central authorities have come under continual criticism (e.g. Úrad vlády 2005; Ministerstvo vnitra 2012a). In autumn 2006, the general coordination of public administration was largely centralized under the responsibilities of the Ministry of the Interior, which became a super-ministry responsible for police, fire prevention, registry offices, civil and travel documents, archiving and coordinating e-government development (after the formal abolishment of the Ministry of Informatics in 2007).

Speaking of coordination of e-government and through egovernment, central governments have been active mainly in the following areas:

1. e-government development framework (strategies and legislation, methodical guides);

2. national institutional and technical support for e-government coordination;

3. central solutions for more integrated and cleaner data sources and delivery of (e-) services.

The following text outlines and discusses their main characteristics.

\section{E-government strategies - high-flying, but not evidence-based}

E-government was not an explicit part of the initial phase of reforms, during which particularly democratization, establishment of basic administrative structure and economic transformation were emphasized. As in other CEE countries (as outlined 
by Verheijen 1998), e-government became more explicit in national reform policies in the late 1990s and later in reaction to eEurope and the subsequent EU policies.

The first national e-government strategies were approved by the government in 1999. This year is perceived as a critical juncture in Czech e-government development (Smejkal 2003; Špaček 2012a), particularly thanks to the approval of the first State Information Policy ("SIP") and the subsequent Concept of Development of Public Administration Information Systems in 1999. Since that time, the aims of national e-government strategies ${ }^{2}$ have been more or less repeated, and central governments have been trying to address the problems that arose when various (Smejkal 2003 speaks about "thousands") mutually inoperable public-administration information systems were established during the 1990s at the central and territorial levels for use in state administration and self-governments. This heterogeneity raised questions about duplications, about the accuracy and validity of data stored in information systems and about the possibilities of overcoming the problems as many suppliers participated in creating solutions at various times. The fragmentation of e-government often required citizens to travel among various authorities in order to settle administrative matters and provide one authority with information that was already stored in the information systems of other authorities.

The first national e-government strategies were later modified to reflect requirements of EU policies (often in a copy-paste way), but their "national core" has remained more or less the same, emphasizing the following (Špaček 2013):

- the role of access to public information (with a certain shift of rhetoric to ehealth and environmental information and with new requirements for accessibility of web pages of public authorities to people with disabilities since 2007);

- the development of more sophisticated e-services that would be accessible via the national portal as well as by a network of contact points (recent strategies added data boxes as a new channel of electronic communication with and inside public administration; the anticipated network of contact points was titled the Czech POINT project and emphasized the area of e-justice);

- basic registers as unified data sources for public administration;

- e-government education of civil servants.

National e-government strategies have not been updated and specified on a continuous and systematic basis. Only the first (and still the most recent) formalized SIS strategy - the Smart Administration Strategy (2007) - was specified and supplemented by action plans, although, as with EU strategies, most of the strate-

2 The following main strategic documents were approved by the Czech central government for e-government development, in chronological order: The Action Plans of SIP were approved in 2000 and 2002, e-Czechia 2006 in 2004, the Smart Administration strategy for the 2007-2015 period in 2007, and the Development of Services for an Information Society and the E-government Implementation in a Territory strategies in 2008. 
gies were broad, dealing with the development of an information society and its enablers with e-government. Often the general e-government strategies did not integrate projects of strong central authorities such as the Ministry of Finance (projects like e-taxes and e-treasury) or the Ministry of Social Affairs (projects like social cards and e-forms).

Czech e-government strategic documents are usually not evidence-based. Their texts do not integrate any evaluation, although some evaluations have been produced by the Czech Statistical Office (CSO), mainly since 2004 (see Špaček 2013). They do not consider the findings of European or other available international benchmarking or other evaluations that would enable at least some strategic analysis of the status quo. The most recent ones, e.g. the Smart Administration Strategy, even relied on very general statements such as "inefficient ICT use", "nonexistence of unified communication structure", "no interconnection of individual registries", "insufficient technical equipment", "low PC literacy of civil servants" and "non-existence of electronic communication in state administration". They were elaborated in parallel to the Integrated Operational Programme and the Integrated Programme on Human Resources and Employment (both were approved by the European Commission in 2007), which work with only very general and particularly output-oriented indicators (such as the number of established basic registers, the increase of new fully electronic administrative agendas and the number of established contact points. Most probably due to political instability, none of the national governments (as appointed in 2009, 2010, 2013 and 2014) approved any e-government-strategy update after 2009.

\section{E-government legislation and methodical guides}

Similarly to strategic documents, e-government legislation emerged in the late 1990s establishing standards for e-government development. A complete enumeration of the legislation would go beyond the limits of this text. Among the most important ones the following are usually listed:

- Act No. 106/1999 on Free Access to Information, which is supplemented by special regulations on the structure of electronically published information and accessibility. Act No. 365/2000 on Public Administration Information Systems (PAIS) is considered the most significant of 2000 , particularly for its promotion of the interoperability of existing solutions. This act defines the general duties of the "long-term management" of PAIS and requires public authorities to have an information strategy elaborated and approved (after 2008) in order to address the long-term objectives of quality and security management and the principles of purchasing, developing and running their information system (as specified in Special Regulation No. 529/2006). The information strategy is supposed to serve to elaborate the documentation of the information system. Both these documents must be certified, and the latter is used by the central meta-information 
system www.sluzby-isvs.cz. Although the Ministry of Informatics was active in the development of methodical guides, available research shows that information strategies are not used for management and are approached quite formally (following the principle "we have them, because we are required to by the legislation” - Špaček 2012b).

- Act on Electronic Transactions and Authorized Conversion of Documents No. 300/2008 (the "e-Government Act") specifies data boxes and related duties for using them (for communication inside public administration, their use is compulsory, and data boxes should replace other communication channels). Act on Basic Registers No. 111/2009 only quite recently came fully into force, ending, to some extent, the long discussions on the legal status of basic registers and their structure and administration.

\section{Development of the national institutional structure for e-government coordination}

E-government coordination has always had to cope with the introduced characteristics of the administrative system, both its fragmentation and the general division of public administration into two subsystems: state administration (with a centralized, hierarchical structure and top-down implementation as leading principles) and territorial self-government (more autonomous, but also exercising state-administration tasks). National e-government projects have always anticipated a subsequent adaptation of information systems by self-governments; sometimes they have even been inspired by innovations achieved in self-governments. Following the critical junctures in e-government strategic planning and legislation, two phases may be differentiated. The first phase is represented by the period from 1989 to $1999 / 2000$, the second by the subsequent years. The first can be characterized as unstable central coordination. The second brought more stability of institutional structures for coordination.

In 1991, the Governmental Commission for SIS was established to remedy the fragmentation and to coordinate the development of a unified SIS. The Commission was supposed to build upon the cooperation with a number of central authorities, which would provide it with drawn-up projects of basic registers - an essential and unique source of data for public administration (register of citizens, register of property, register of business entities, and a register of territorial identification was anticipated to be established in that time). The SIS Information Agency was supposed to be established, as well as a portal of municipalities, as a result of cooperation with the Union of Towns and Municipalities. In 1993, the competence of the Commission was transferred to the Ministry of Economic Affairs and then to the Office of the Government, the Department of SIS Management. November 1996 witnessed the establishment of an SIS Office ("ÚSIS"), which took over the Department's agenda. The provisioning act on ÚSIS, however, failed to specify its respon- 
sibilities. Therefore, its position throughout its existence was perceived as weak and inferior in the game with strong central authorities, which "was favoured by most ministries wishing to spend money freely for whatever IT equipment they wanted" (Smejkal 2003). The Governmental Committee for Information Policy was formed in 1998 with the aim of coordinating information policy and closely cooperating with ÚSIS. However, this did not change the situation, either.

The act on PAIS from 2000 established the Office for Public Information Systems ("UVIS"), which replaced and specified its responsibilities (including issuing standards and the possibility of imposing sanctions). However, in relation to the strong departmental ministries, this office was again perceived as subordinate in communication (Smejkal 2003), and the ÚVIS could not overcome departmentalism and the tendency of some central authorities (and their units) to act independently. There is no information on it ever imposing any sanctions.

In 2003, UVIS was dissolved and its responsibilities delegated to the newly established Ministry of Informatics, which exercised its coordination tasks mainly through regulatory instruments (standards) and methodological guides. It also contributed to the start-up of a national public-administration portal (portal.gov.cz), launched officially in November 2004 and aimed at businesses and citizens rather than public authorities. The Ministry prepared an amendment to the law which introduced requirements on accessibility and the duties of long-term e-government management. However, little was changed in terms of regulation and the subsequent practices with the basic registers. The persistent problems with evaluating e-government are clear, as the reports produced by the Ministry tackled especially the preconditions of e-government development (adoption of new legislation or policies, wider use of the internet), rather than the outcomes of implemented projects (Špaček 2012a).

The institutional structure for e-government coordination became more stable after the Ministry of Informatics was abolished in July 2007 and the Ministry of the Interior was given the general responsibility of managing and coordinating e-government (although it had originally been anticipated that e-government management would be entrusted to the Office of the Government for its supra-departmental potential). Considering the multiple areas of its responsibilities (including police and fire prevention, registry offices, civil and travel documents, archiving and e-government), the Ministry of the Interior has become a large multi-objective bureaucracy, a kind of super-ministry

\section{Current mechanisms of central e-government coordination - an example of sleeping accountability?}

After the e-government management was centralized under responsibilities of the Ministry of the Interior, a coordination structure was established by e-government policy and legislation, as simplified in Figure 1. It can be summarized as follows: 
- The Ministry of the Interior is a key player which cooperates with the other external stakeholders depicted. It provides coverage for the public-administration portal as well as meta-information systems (www.sluzby-isvs.cz) and standardizes the disclosure of public information and provides methodical help. The Smart Administration strategy anticipated the appointment of the Group for Smart Administration Coordination, which coordinates the elaboration and evaluation of projects. This role is assumed by one of the departments of the Ministry of the Interior, the Structural Funds Department. Coordinated by the Ministry, the Smart Administration inter-departmental workgroup was also established, which is responsible for revising and updating strategic documents and evaluating their implementation.

- The Gremium for Regulatory reform and Efficient Public Administration was established as an inter-ministerial coordinating body of the Smart Administration strategy. Chaired by the Minister of the Interior and consisting of representatives of central authorities, associations of self-governments and the Economic Chamber, it comments on legislation proposals, approves project proposals and comments on proposals of mid- and long-term strategies, analyses and programmes.

- The Government Council for an Information Society was established in spring 2007 as an advisory body for the "higher interconnection and coordination of ministerial projects". It is chaired by the Prime Minister and consists of ministers and representatives of state administration and self-governments.

- With regard to the major significance of basic registers, officially launched into practice in July 2012, a specific coordinating role is assumed by the National Registers Authority (SZR). This body manages the basic register information system (ISRZ). Since the individual registers have their own administrators ${ }^{3}$, they also add to the burden on the coordination processes. The Office for Personal Data Protection (ÚOOÚ) is required to make sure that the identification of people working with the basic registers will be safe and transparent.

- In order to implement the E-government Implementation in a Territory strategy, "eGON centres" were established in 14 regions and 205 ORPs to link egovernment development with their needs and take into account a nationally standardized set of basic e-services and as-yet-undefined standards of e-government strategic planning. eGON centres are responsible for "technological centres" allowing the establishment, operation and maintenance of a standardized infrastructure necessary for small municipalities processing the key data of basic registers and other applications (such as file-service systems).

3 The Ministry of the Interior manages the Register of Inhabitants and the Register of Rights and Responsibilities; the Czech Statistical Office takes care of the Register of Persons; and the Czech Office for Surveying, Mapping and Cadastre is responsible for the Register of Territorial identification, Addresses and Real Estates. 
The e-government coordination was fragmented in the organizational structure of the Ministry of the Interior, and in terms of political and executive leadership it has been very unstable, even during a term of office of the same minister. Since autumn 2009, various reorganizations at the Ministry were made, followed by personnel changes in top political and executive positions. For instance, following a change in the ministerial post, the formerly established Office of the Deputy for Public Administration, Informatics, Legislation and Archiving was split into the responsibilities and personnel of the Deputy for Public Administration, Legislation and Archiving and the Deputy for Informatics. This division was motivated by the tendency of the former sub-system to concentrate mostly on e-government rather than on other issues in public administration (Chum 2009). After the change, the office headed by the first deputy was responsible for creating project assignments, and the office of the second deputy was required to offer means for their implementation.

Czech media monitored the personnel changes, pointing out that between summer 2010, when a new right-wing government was appointed, and spring 2011, the Deputy for Informatics changed seven times (eGov.cz 2011). Within the 2012-2013 term of office, the deputy responsible for public administration and egovernment changed three times, and there were also changes in the ministerial post in 2011, 2013 and 2014, partly caused by political crises. Furthermore, the legal status of Czech civil servants was specified only partly and only for civil servants of self-governments.

The frequent changes in political leadership have been criticized by the European Commission and have prompted discussions and restrictive precautions in IOP funding (Česká pozice 2012). Such changes lead to situations in which people that are to be held accountable for previous mismanagement often are no longer in office, as pointed out by Veselý (2013). Veselý explains "sleeping accountability" as a CEE phenomenon characterized by the discrepancy between the formal existence of many accountability mechanisms and their actual performance (see also Nemec et al. 2008). Sleeping accountability is demonstrated by the Czech e-government. Although its development has been relatively long, almost no evaluation has been published by responsible bodies since it started, and one can only deduce the features of e-government management from the practices as criticized by the EU, Czech media and supervisory institutions (such as the Office for the Protection of Competition or the Supreme Audit Office), which also point out that more than $60 \%$ of the ICT public tenders organized by central authorities are awarded without competition (Špaček 2012a).

Since 2007, the Ministry of the Interior has not published any summary information on the evaluation of e-government, and its evaluation is neither regular nor ad hoc. As summarized by Špaček (2013), the information published does not yet include a comprehensive evaluation of the most heavily promoted national proj- 


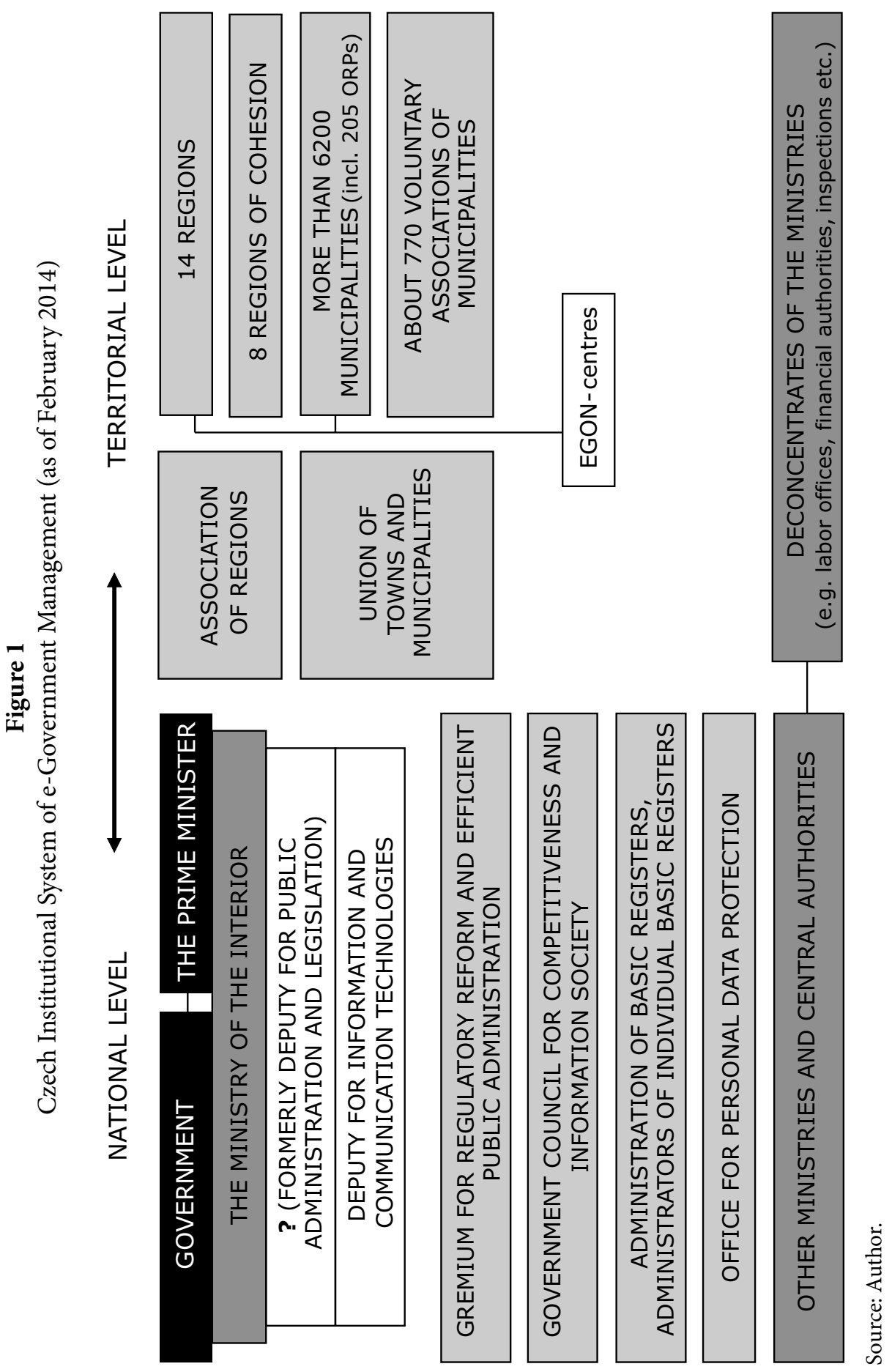


ects (Czech POINT, data boxes and basic registers). Although some projects were launched years ago, available evaluations refer only to total numbers (of extracts generated through Czech POINTs, messages sent through data boxes and activities conducted in basic registers, etc.). The Group for Smart Administration Coordination has only published a list of projects proposed for EU funding, without commenting on their prioritization or cost-benefit characteristics. Annual reports on the Smart Administration status quo (Ministerstvo vnitra 2011 and 2012b) are very superficial and limited to information such as statements that most of the planned activities have been carried out or that calls for projects have been announced. The reports also provide data such as the total money spent and information on the fulfilment of output-oriented indicators defined by the Integrated Operational Programme. The current national e-government evaluation still focuses mainly on the quantifiable aspects of e-services and outputs (such as the number of existing services, the number of visits, the total money spent on education via individual eGON centres, etc.), rather than on the outcomes, including user satisfaction.

Issues of national e-government coordination are demonstrated in the critical opinions of the representatives of self-government. For instance, in September 2012, three months after the basic registers had been launched, a Chrudim municipality mayor stated: "We should consider the fact that throughout the whole period of transition to basic registers, the office and the accountable workers struggled with multitudes of contradictory, fragmented, and incomplete information that could hardly provide a complex image on what and how the office should get ready for running the registers. The hardest work to gain specific information and the assurance of procedures and complete readiness cannot currently be secured, despite the declarations of the state on the functioning of registers." (Pacinová 2012, 8). In April 2012 , representatives of the CSO, the authority responsible for one of the basic registers, the Register of Inhabitants, complained that although the necessary data had been requested months before, public authorities had not yet sent it, which could delay the launch of the register.

The evaluation transparency and the possibilities for coordinating through egovernment are further hindered by the existence of various electronic sources of official information. Information is published relatively independently and incoherently on the websites of individual authorities (ministries, SZR) and of individual projects as well as on the www.smartadministration.cz website.

\section{Central solutions for more integrated and cleaner data sources and the delivery of (e-) services - examples of improvements, unclear visions and flaws}

The central government has been developing central solutions for a more interconnected delivery of some public services that had previously been provided in a fragmented way, with their provision often bound to the permanent residence 
of a citizen and requiring citizens to travel to various public authorities. The available national evaluation (as summarized by Špaček 2013) and the last European benchmarking report indicate that some improvements have been achieved and coordination has been enhanced through e-government in the country. Researching the Czech key national e-government projects, we may find examples of some that brought improvements and some that caused worsening (downgrades of former solutions) and call for enhanced coordination.

\section{Czech POINT project - improved coordination through more joined-up services}

The Czech POINT project is an example of an innovative approach. Following the principles of voluntariness and economic motivation by the central government (through subsidies co-funded by the EU), the project has brought more cooperative and interconnected service delivery and enhanced the ability of central government to coordinate the delivery of public services through the establishment of a network of contact points built on a one-stop-shop principle.

Since its official start in 2008, the project has been incrementally offering, through a growing and increasingly integrated network of one-stop shops (called Czech POINTs), an alternative channel of delivering government services. Citizens and businesses no longer have to visit several public authorities to obtain certain services and can now visit one of more than 7,000 Czech POINTs (situated mostly in municipal offices and branches of Czech Post, in lesser cases at regional offices, branches of chambers of commerce and notaries, and, since quite recently, branches of one bank). The project has improved processes in the existing institutional system, making service delivery faster through the enhanced integration and horizontal and vertical coordination by the central authority. The following categories of services are now being provided by the Czech POINT system:

- issuing of authenticated extracts - e.g. extracts from the Cadastre of Real Estate, the Companies Register, Crime Register - as operated before rather individually by the Central Cadastre Office, Trades Licensing Office and Ministry of Justice of the Czech Republic (deconcentrated to 205 municipal offices). Citizens may obtain extracts from some basic registers, if they are required to do so, particularly by banks or other institutions outside public administration;

- intermediation of some submissions (e.g., submissions according to the Trades Licensing Act and for revisions of data in basic registers);

- conversion of paper documents into authorized electronic versions and vice versa;

- internal use of extracts (such as extracts from the Crime Register). These functionalities represent the only government-to-government Czech POINT services. Civil servants are required to use the Czech POINT information system 
to obtain some extracts and data already registered in PAIS without requiring citizens to bring them;

- functionalities related to data boxes (application for their establishment and administration of rights);

- services fully available online via the Czech POINT E-SHOP, which offers only limited services (electronic applications for authorized versions of extracts from publicly accessible information systems).

Although the plans of the Ministry were ambitious and the number of Czech POINT services has been growing, Czech POINT is currently represented by a network of physical terminals providing reception services during their office hours. The project clearly attempts to transfer the administrative burden from the citizens back to public administration, and to some extent it has succeeded. In 2012, however, the CSO in its survey results pointed out that $30 \%$ of population did not know about the project, $51 \%$ were aware of the project, but had not used it, and only $10 \%$ had actually used any of the Czech POINT services at least once (Czech Statistical Office 2012). The survey method of the CSO did not research the incentives for using Czech POINT services (or services offered by other key e-government projects) or aspects of user satisfaction.

\section{National public administration portal-promising in the past, unclear for the future}

The national public-administration portal (portal.gov.cz) represents one of the oldest initiatives, improving since its pilot testing in September 2003. Its information services have been reshaping and growing (mainly due to the growing number of available live event descriptions), and for some time it offered transaction services (electronic submissions of some documents relevant for pension insurance, tax declarations, announcements of pollution, insertion of data for evaluating the exams of applicants for driving licenses).

In February 2012, the transactional part of the portal was restricted by the Ministry of the Interior, which proposed that its functionalities systems would be replaced by the data-boxes portal (established in June 2011 for accessing data boxes) without larger communication with users or with authorities such as the Ministry of Labour, which had been providing services through the former portal and had to quickly adapt and prepare their alternative e-submission instruments (Peterka 2011). In October 2011, the introductory web page of the data-boxes portal announced that it would become a portal from which users could access intelligent eforms as well as their data boxes, and that the Ministry of the Interior had been negotiating with individual authorities in order to make them provide users with such e-forms. In March 2012, the design of the portal.gov.cz had changed, and although it was called innovative by the Ministry, its transactional part was missing. As of February 2014, only the information part of the portal remains, only established 
data boxes can be accessed, and the data-boxes portal (www.mojedatovaschranka. $\mathrm{cz}$ ) offers no e-forms.

\section{E-government deforms? - ICT support of social reform and register of vebicles as examples}

Municipalities have criticized the central government's approach to social-administration reform since 2012, when the provision of social-security benefits was transferred from ORPs to a newly-organized Labour office, while the municipalities remained responsible for social work. Available comments indicate that the reform was not explained sufficiently prior to its implementation by the Ministry of Labour and that the project was certainly not well prepared. The change was followed by new ICT solutions, which did not work properly for almost a year (blackouts, data losses and slackness are mentioned in the comments of media and users), and some people received social benefits only after significant delays (Chum 2013). More businesses had to work on the solution, the Ministry did not launch the public tender for it, and the media criticized the exorbitant price of the revision and the lack of transparency of the revisions (which is being investigated by the Office for the Protection of Competition).

The registry of vehicles represents a similar case. A new registry was launched in 2012, antedated by transfers of responsibilities for its management from the Ministry of the Interior to the Ministry of Transport. The launch itself was accompanied by the register breaking down and long-term malfunctions, which affected the municipal offices of ORPs as the front-line providers of registration services. In mid-August, people were still queuing at the offices because the new system was far slower, and the malfunctions required that officials work simultaneously in the old and the new systems. The media continuously reported that citizens relieved themselves of their legally defined obligations to register their vehicles and resorted to damage claims (Česká televize 2013).

\section{Concluding remarks}

So what are the roles and trends of coordination of and through e-government? The presented text clearly shows that coordination and e-government are two mutually interlinked concepts. E-government may be an object as well as an instrument of coordination by the central government, and these aspects cannot be separated without difficulties. Both aspects are visible in practices across Europe, where governments work with a mix of instruments aimed at enhancing the centralization of their e-government development through new centrally promoted infrastructures and services that allow for more integrated service delivery, virtual or physical, and through changes in organizational structures established for coordination. 
Some of the challenges that governments may face when coordinating e-government and through e-government are illustrated by the Czech development. The paper clearly shows that the Czech central government and central executive authorities have not been passive in terms of the rhetoric of coordination and practical approaches to coordination of and through e-government. Challenges, which have been faced during the e-government development, can be linked to the following rather interlinked themes:

- high proliferation of ICT solutions and departmentalism;

- deficiencies in strategic planning and project management;

- lack of stability of national institutional structure for e-government cooperation;

- insufficient national evaluation.

The paper shows that new coordination practices emerged and were evoked by necessity to solve the high proliferation of ICT solutions implemented on various levels of state administration and government as a consequence of uncoordinated administrative fragmentation in the first post-communist decade.

The presented text implies that in the 1990s, the first decade of the post-communist history, the activities of the central government focused on the last levels of Metcalfe's coordination scale, particularly in the government strategy and the establishment of central priorities. However, it neglected the initial levels of the scale (independent decision-making of individual actors). Even the e-government strategy was not compact and in the form of a document integrating clear goals for the future. 1999 was crucial thanks to the approval of the first e-government strategy and also due to the approval of the first general e-government legislation that aimed at the standardization of management. This brought mainly the standardization of e-government policy (strategic planning), which became more or less a stable part of the thinking of the central government and its authorities, and basic principles of further e-government development and management. It was not followed by the stabilization of central institutional mechanisms that were supposed to coordinate e-government within a specified framework.

The paper also shows that although the institutional structure was stabilized to a larger extent than in previous years in 2007 when the Ministry of the Interior took over the responsibilities of the formerly existing Ministry of Informatics, other issues that hinder coordination of and through e-government persist. Obviously, the coordination should relate to policy as well as administration and the major unknown in the practice remains the balance between a focus on joined-up policy design and a focus on administration, since even when underlying policies are consistent, their implementation may not be necessarily compatible. This can be overcome (or at least indicated) by evaluation, which recently became a very visible topic in international e-government literature (Špaček 2013). This has been reflected in new duties and methodological guides in some European countries in response to pressure from the EU and other international organizations such as the OECD. 
Although the Czech Smart Administration strategy from 2007 called for continual monitoring and evaluation of the quality of public services, and relevant duties were specified even before in legislation or in supplemental governmental operational documents, e-government management is still not transparent, national evaluation is scarce, and available reports indicate that e-government development and coordination is hardly evidence-based. Rather it is driven by opportunities to use EU funding and facilitated by mechanisms of support from EU funds. This raises the relevancy of the concept of sleeping accountability even higher due to frequent changes in political and executive management (and coordination) limiting the consistent long-term development of e-government. These changes also prevent top civil servants from holding pivotal positions in enhancing interdepartmental coordination (Hansen et al. 2012).

The introduced examples indicate that coordination may be enhanced through e-government. On the other hand new solutions may be damaging, downgrading the former solutions. The examples used indicate that often the role of stakeholder inclusion in designing strategies is neglected, in turn hindering the implementation of e-government projects and their coordination. This may cause distrust and a priori negative perception of what is and will be going on at the national level.

\section{Funding}

This paper was supported by a Czech Science Foundation Grant (P403/12/0366).

\section{References}

Accenture. 2009. "Web 2.0 Collaboration Tools for the Next Generation of Public Service." Available at http://www.accenture.com/us-en/Pages/insightweb-2.0-collaboration-tools-public-service.aspx (last accessed 25 October 2011).

Bouckaert, G., B. G. Peters and K. Verhoest. 2010. The Coordination of Public Sector Organizations. Houndmills: Palgrave Macmillan.

Česká pozice. 2012. "Ministerstvu vnitra mohou vyschnout eurodotace." Available at http://www.ceskapozice.cz/domov/politika/ministerstvu-vnitra-mohouvyschnout-eurodotace (last accessed 20 February 2014).

Česká televize. 2013. “Ani po roce registr vozidel nefunguje bezchybně.” Available at http://www.ceskatelevize.cz/zpravodajstvi-brno/zpravy/233978-ani-poroce-registr-vozidel-nefunguje-bezchybne/ (last accessed 5 May 2014).

Chen, Y. 2010. "Citizen-Centric E-government Services: Understanding Integrated Citizen Service Information Systems." Social Science Computer Review 28(4), 427-442. 
Chum, J. 2013. “Připadali jsme si skoro jako v Kocourkově.” Veřejná správa 1, 10-11.

Chum, J. 2009. “Je třeba mít dlouhodobé strategie." Veřejná správa 24, 8-10.

Czech Statistical Office. 2012. Informační a komunikační technologie ve veřejné správě v roce 2011. Praha: ČSÚ.

De Vries, M. and J. Nemec. 2013. "Public Sector Reform: An Overview of Recent Literature and Research on NPM and Alternative Paths." International Journal of Public Sector Management 36(1), 4-16.

eGov.cz. 2011. "Na MV je informatika za poslední 3 měsíce pod třetím náměstkem." Available at http://www.egov.cz/index.php?option=com_ content\&view=article\&id=144:na-mv-je-informatika-za-posledni-3-msicepod-tetim-namstkem\&catid=2:komentaraapostrehy\&Itemid $=4$ (last accessed 18 February 2014).

Epractice.eu. 2014a. "eGovernment in Hungary, April 2014." Available at http:// www.epractice.eu/files/eGovernment\%20in\%20HU\%20-\%20April\%20 2014\%20-\%20v.16.pdf (last accessed 5 May 2014).

Epractice.eu. 2012a. "eGovernment in Finland, March 2010." Available at http:// www.epractice.eu/files/eGovernmentFinland.pdf (last accessed 5 May 2014).

Epractice.eu. 2012b. "eGovernment in Sweden, January 2012.” Available at http:// www.epractice.eu/files/eGovernmentSweden.pdf (last accessed 5 May 2014).

Epractice.eu. 2012c. "eGovernment in Denmark, January 2012." Available at http:// www.epractice.eu/files/eGovernmentDenmark.pdf (last accessed 5 May 2014).

Epractice.eu. 2012d. "eGovernment in Spain, January 2012." Available at http:// www.epractice.eu/files/eGovernmentSpain.pdf (last accessed 5 May 2014).

Epractice.eu. 2011a. "eGovernment in the Netherlands, January 2011." Available at http://www.epractice.eu/files/eGovernmentTheNetherlands.pdf (last accessed 5 May 2014).

Epractice.eu. 2011b. “eGovernment in Estonia, December 2011." Available at http:// www.epractice.eu/files/eGovernmentEstonia.pdf (last accessed 5 May 2014).

Epractice.eu. 2011c. "eGovernment in Austria, October 2011." Available at http:// www.epractice.eu/files/eGovernmentAustria.pdf (last accessed 5 May 2014).

Epractice.eu. 2011d. "eGovernment in Italy, December 2011." Available at http:// www.epractice.eu/files/eGovernmentItaly.pdf (last accessed 5 May 2014).

Epractice.eu. 2011e. "eGovernment in Malta, December 2011." Available at http:// www.epractice.eu/files/eGovernmentMalta.pdf (last accessed 5 May 2014). 
Estevez, E., T. Janowski, A. Ojo and I. K. Khan. 2007. "Coordination Offices for eGovernment.". Available at http://www2.iist.unu.edu/www/docs/techreports/ reports/report363.pdf (last accessed 5 May 2014).

European Commission. 2010a. "A Digital Agenda for Europe." Available at http://eur-lex.europa.eu/LexUriServ/LexUriServ. do?uri=COM:2010:0245:FIN:EN:PDF (last accessed 26 October 2011).

European Commission. 2010b. "The European eGovernment Action Plan 2011-2015.” Available at http://ec.europa.eu/information_society/activities/ egovernment/action_plan_2011_2015/docs/action_plan_en_act_part1_ v2.pdf (last accessed 26 October 2011).

Hansen, M. B., Steen, T., De Jong, M. 2012. "New Public Management, Public Service Bargains and the challenges of interdepartmental coordination: a comparative analysis of top civil servants in state administration." International Review of Administrative Sciences 79(1), pp. 29-48.

Heeks, R. 2006. Implementing and Managing eGovernment. London: SAGE Publications Ltd.

Homburg, V. and I. Snellen. 2007. "Will ICTs Finally Reinvent Government? The Mutual Shaping of Institutions and ICTs." In Ch. Pollitt, S. Van Thiel and V. Homburg (eds). New Public Management in Europe: Adaptation and Alternatives. New York: Palgrave Macmillan, 135-148.

Hu, G., W. Pan and J. Wang. 2010. "The Distinctive Lexicon and Consensual Conception of e-Government: An Exploratory Perspective." International Review of Administrative Sciences 73(3), 577-597.

Kudo, H. 2008. "Does e-Government Guarantee Accountability in Public Sector? Experiences in Italy and Japan." Public Administration Quarterly 32(1), 93-120.

Kunstelj, M. and M. Vintar. 2009. "One-Stop Government: Critical Analysis of the Concept and its Implementation in the Selected Countries." Paper for NISPAcee 2009 Annual Conference, Budva, Montenegro.

Löfgren, K. 2007. "The Governance of E-government: A Governance Perspective on the Swedish E-government Strategy." Public Policy and Administration 22(3), 335-352.

Makolm, J. 2006. "A Holistic Reference Framework for e-Government: The Practical Proof of a Scientific Concept." Available at http://www.ebusinessforum.gr/ old/content/downloads/HolisticReferenceFramework.pdf (last accessed 10 February 2014). 
Ministerstvo vnitra. 2012a. "Analýza aktuálního stavu veřejné správy." Available at: http://www.mvcr.cz/soubor/analyza-aktualniho-stavu-verejne-spravy-pdf. aspx (last accessed 2 June 2014).

Ministerstvo vnitra. 2012b. "Roční zpráva o stavu Smart Administration". Available at: http://www.smartadministration.cz/soubor/952-12-zpravasa-pdf.aspx (last accessed 2 June 2014).

Ministerstvo vnitra. 2011. "Roční hodnotící zpráva o plnění strategie Smart Administration." Available at: http://media1.nolimit.cz/files/media1:50fd5a830fbb2. pdf.upl/ma_rack8mcjculr.pdf (last accessed 2 June 2014).

Národní vzdělávací fond. 1998. “Analýza veřejné správy České republiky." Available at: http://old.nvf.cz/archiv/versprava/analyza/obsah.htm (last accessed 2 June 2014).

Nemec, J., F. Ochrana and M. Sumpikova. 2008. "Czech and Slovak Lessons for Public Administration Performance Evaluation, Management and Finance." Ekonomicky časopis 56(4), 353-369.

OECD. 2009. Rethinking e-Government Services: User-Centred Approach. Paris: OECD.

OECD. 2003. E-Government Imperative. Paris: OECD.

Pacinová, Z. 2012. “Základní registry v obcích," Veřejná správa 18, 8-9.

Peterka, J. 2011. “Portálová rošáda: Portál datových schránek.” Available at http:// www.lupa.cz/clanky/portalova-rosada/ (last accessed 1 August 2013).

Saner, R., G. Tosefa, A. Atramanov, R. Mogilevsky and A. Sahov. 2008. "Government Governance (GG) and Inter-Ministerial Policy Coordination (IMPC) in Eastern and Central Europe and Central Asia." Public Organization Review $8,215-231$.

Siau, K and Y. Long. 2005. "Synthesizing e-Government Stage Models: A MetaSynthesis Based on Meta-Ethnography Approach." Industrial Management \& Data Systems 105(4), 443-458.

Smejkal, V. 2003. Informační systémy veřejné správy ČR. Praha: VŠE.

Snellen, I. and M. Thaens. 2008. "From e-Government to m-Government: Towards a New Paradigm in Public Administration?" Available at http://unpan1. un.org/intradoc/groups/public/documents/CAIMED/UNPAN028992.pdf (last accessed 12 December 2009).

Špaček, D. 2013. "National Approach to e-Government Evaluation: Challenges of Accountable (e-)Government in the Czech Republic." In M. Vintar, A. Aristovnik and L. Todorovski (eds). Modern Approaches, Metrics and Indicators for Monitoring and Evaluating Public Policies. Ljubljana: Faculty of Administration, 265-300. 
Špaček, D. 2012a. E-Government: Cíle, trendy a př́istupy k jeho hodnocení. Praha: C. H. Beck.

Špaček, D. 2012b. "Information Strategies of Czech Statutory Cities and Regions: Critical Remarks." Knowledge Management: An International Journal 12(3), $31-46$.

Špaček, D. and J. Špalek. 2007. "Communication and Electronic Public Administration: Some Issues in the Context of the Czech System of Public Administration." In J. Nemec (ed.). Lessons and Recommendations for Improvement: Central and Eastern European Public Administration and Public Policy. Bratislava: NISPAcee, 217-238.

Tinholt, D., N. van der Linden. 2012. "Public Services Online: 'Digital by Default or by Detour?"' Available at https://ec.europa.eu/digital-agenda/sites/digitalagenda/files/eGov_Benchmark_2012\%20background\%20report\%20published\%20version\%200.1\%20.pdf (last accessed 12 February 2014).

Úřad vlády. 2005. "Reforma ústřední správy: Návrh dalšího postupu realizace reformy a modernizace ústřední státní správy v letech 2005-2010." Available at http://statorg.cmkos.cz/news/0305_ref_ustr_st_spr/0305material_ref_ustr_ st_spr.doc (last accessed 2 June 2014).

Verheijen, T. 1998. "Chapter 1: The Management of EU Affairs in Candidate Member States: Inventory of the Current State of Affairs." SIGMA Papers 23, 16-40.

Veselý, A. 2013. "Accountability in Central and Eastern Europe: Concept and Reality." International Review of Administrative Sciences 79(2), 310-330.

Willems, T. and W. Van Dooren. 2011. "Lost in Diffusion? How Collaborative Arrangements Lead to an Accountability Paradox." International Review of Administrative Sciences 77(3), 505-530. 